
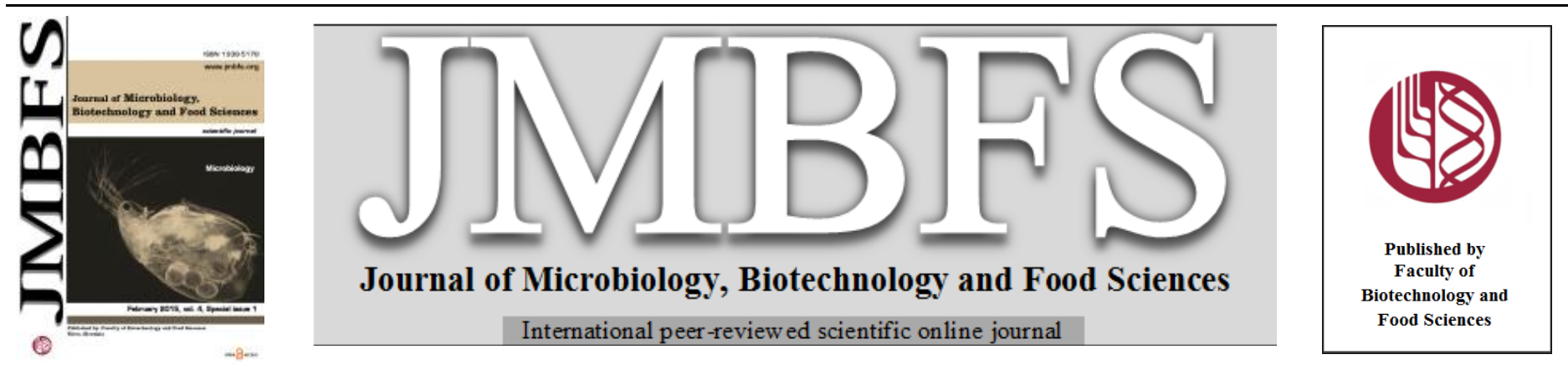

\title{
NATURAL MICROFLORA OF WINE GRAPE BERRIES
}

\section{Attila Kántor $^{*}$, Miroslava Kačániovál, Maciej Kluz ${ }^{2}$}

Address(es): Mgr. Attila Kántor,

${ }^{1}$ Department of Microbiology, Faculty of Biotechnology and Food Sciences, Slovak University of Agriculture in Nitra, Trieda Andreja Hlinku 2, 94976 Nitra, Slovakia.

${ }^{2}$ Department of Biotechnology and Microbiology, Faculty of Biology and Agriculture, University of Rzeszow, Zelwerowicza 4, 35-601, Rzeszow, Poland.

*Corresponding author: kantor.spu@gmail.com

doi: 10.15414/jmbfs.2015.4.special1.32-36

ARTICLE INFO

Received 13.11.2014

Revised 17. 12. 2014

Accepted 25. 12. 2014

Published 2. 2. 2015

Regular article oPEN $\partial_{\text {ACCESS }}$

\section{ABSTRACT}

The diversity of yeasts and bacterial species on grapes has been investigated in vineyards worldwide. For winemaking are very important three groups of microorganisms. First two includes acetic acid and lactic acid bacteria; they live and grow normally on grape surface. The third group includes more than 20 detectable genera of yeasts. There are three principal genera found on grapes Hanseniaspora uvarum (Kloeckera apiculata), Metschnikowia pulcherrima (Candida pulcherrima), and Candida stellata or new descripted Candida zemplinina. Aim of this study was investigate of number of three major groups of microorganisms which are important for grapes and winemaking. The number of bacteria on Acetobacter agar (AA) ranged from $1.76 \log \mathrm{CFU} / \mathrm{mL}$ to $2.80 \log$ $\mathrm{CFU} / \mathrm{mL}$. Lactic acid bacteria were counted on MRS agar and the number of detectable colonies ranged from $0.48 \log \mathrm{CFU} / \mathrm{mL}$ to 2.06 $\log \mathrm{CFU} / \mathrm{mL}$. Sabouraud dextrose agar (SDA) was used for cultivation of yeast and the number of yeasts ranged from $2.47 \log \mathrm{CFU} / \mathrm{mL}$ to $2.76 \log \mathrm{CFU} / \mathrm{mL}$. For identification of yeast species were used different types of agar media with acid base indicator bromocresol green. Identified 10 yeasts species includes to genus: Candida, Metschnikowia, Pichia, Kluyveromyces, Hanseniaspora, Hansenula, Candida, Debaromyces, Rhodotorula and Saccharomyces. We identified only few bacterial species includes to genus Lactobacillus, Pediococcus, Gluconobacter and Acetobacter.

Keywords: Grapes, identification, yeasts, bacteria

\section{INTRODUCTION}

Numerous studies have analyzed the presence of yeast on the surface of grapes (de Andrés-de Prado et al., 2007; Fleet, 1990) and many have indicated that Saccharomyces cerevisiae is present only in very small numbers on healthy grapes (Martini, 1993; Pretorius, 2000). The most frequently isolated native species is Kloeckera apiculata, which may account for more than $50 \%$ of the total yeast flora recovered from fruit. Lesser numbers of other yeasts, such as species of Candida, Cryptococcus, Debaryomyces, Hansenula, Issatchenkia, Kluyveromyces, Metschnikowia, Pichia, and Rhodotorula, have also been reported (Fleet, 1990; Velázquez et al., 1991; Sabate et al., 2002). The grape microflora, however, varies greatly depending on factors such as geographical location, rainfall and temperature (Longo et al., 1991; Parrish and Carroll, 1985), fungicide use soil type, vineyard age, grape variety and harvesting method (Pretorius et al., 1999; Rosini et al., 1982). Fermentative yeasts include those responsible for wine fermentation, where $S$. cerevisiae is the most important, but other species ( $S$. bayanus, S. pastorianus and $S$. paradoxus) may also conduct or participate in the process (Josepa, 2000; Arroyo López et al., 2010) Saccharomyces can be found in grape musts, but the populations are often less than $50 \mathrm{CFU} / \mathrm{mL}$ (König et al., 2009).

Failure to routinely isolate Saccharomyces from the vineyard could reflect the preference of this yeast for the high-sugar environments of grape juice and fermentation. However, the use of direct isolation techniques showed a much different picture, revealing that Saccharomyces spp. is an absent or rarely found on grapes (Davenport, 1974). Concerning yeasts, the innocent group includes basidiomycetous species which are regarded as irrelevant to winemaking due to their inability to ferment juice sugars or to survive in wines. The ascomycetous dimorphic fungus, Aureobasidium pullulans (also called black yeast), a common yeast-like species, is also technologically irrelevant. The oxidative, weakly fermentative or fermentative ascomycetous species (Candida spp., Kloeckera apiculata / Hanseniaspora uvarum, Metschnikowia spp., Pichia spp.) are present in pre-fermentation steps or at the beginning of fermentation. The fermentation ability is not a well-defined taxonomic feature and several species may be regarded as weakly fermentative or not (Romano et al., 1997).
Like yeasts, lactic acid bacteria are also present in vineyards. Species that have been isolated from grapes include Lactobacillus hilgardii, L. plantarum, L. casei, $O$. oeni, Leuconostoc mesenteroides, and P. damnosus (Lonvaud-Funel et al., 1999). Acetic acid bacteria are commonly associated with grapes and are normally present in wine must. Unspoiled grapes are reported to have $10^{2}-10^{3}$ $\mathrm{CFU} / \mathrm{g}$, whereas spoiled and damaged grape can contain more than $10^{6} \mathrm{CFU} / \mathrm{g}$ (Bartowsky, 2009). Where mold growth, particularly Botrytis cinerea, and grape damage develop increase of populations and diversity of acetic acid bacteria not only G. oxydans but A. aceti or A. pasteurianus. In agreement, González et al. (2006) reported a major presence of both $G$. oxydans and A. aceti in spoiled grapes.

Concerning bacterial species, acetic acid bacteria are regarded as innocent because they are easily controllable in the winery, although the exaggerated production of acetic acid during grape sour rot is a serious threat to wine quality. The physiological diversity of lactic acid bacteria does not allow a precise assessment of their technological significance. The typical agent of malolactic fermentation is $O$. oeni while Lactobacillus spp. and Pediococcus spp. may be responsible for spontaneous fermentations (Lerm et al., 2010). These species may spoil wine when their activity goes beyond malic conversion, particularly in high $\mathrm{pH}$ wines, producing off flavors or biogenic amines (Arena et al., 2011; Capozzi et al., 2011; Pan et al., 2011). Grapes also bear a wide diversity of bacterial species common in nature or in other food related environments.

Understanding microbial ecology during vinification is further complicated by mounting evidence that microorganisms can also exist in a state known as "viable but non culturable" (VBNC). By definition, microorganisms in the VBNC state fail to grow on microbiological media yet display low levels of metabolic activity (Oliver, 2005).

Microorganisms found in wine and believed to be able to enter a VBNC state are Acetobacter aceti, Brettanomyces bruxellensis, Candida stellata, Lactobacillus plantarum, Saccharomyces cerevisiae, and Zygosaccharomyces bailii (Millet and Lonvaud-Funel, 2000; Divol and Lonvaud-Funel, 2005; Du Toit et al., 2005; Oliver, 2005).

The objectives of this study were to investigate the occurrence of natural microflora of grape berries in four different varieties of wine grape berries from 
Nižné Valice village. Identification of three groups of microorganisms includes yeasts, lactic acid bacteria and acetic acid bacteria on grape berries with classical microbiological methods.

\section{MATERIAL AND METHODS}

\section{Collection of grape berries}

Grape berries were collected nearby Nižné Valice village. We collected four different varieties of wine grape berries, five times from one variety aseptically with gloves. The wine berries were collected from wine varieties: Blaufränkisch 2014, Cabernet Sauvignon 2014, Rhein Riesling 2014 and Welschriesling 2014 Ten berries from each variety was putted into the $50 \mathrm{~mL}$ centrifuge tubes (five times from each grape variety) with $25 \mathrm{~mL}$ of physiological saline, and stored at dark cold place for next analysis (20 samples).

\section{Determination of CFU and cultivation media}

For microbiological analysis the grape samples in physiological saline were processed to 24 hour after collection. For classical microbiological method - plate count method was use three specific cultivation media. We used Sabouraud dextrose agar (SDA, Conda Spain) for yeast, Acetobacter agar (glucose) (AA, HiMedia, India) for Acetobacter species and MRS (Conda, Spain) agar medium for lactic acid bacteria. Plate diluting method was applied for quantitative CFU (Colony Forming Units) counts determination of respective groups of microorganisms in $100 \mu \mathrm{L}$ of bacterial solution, which inoculated into the agar medium surface. Petri dishes of gelatinous nutritive substrate were inoculated with $100 \mu \mathrm{L}$ of bacterial solution from grape surface in three replications. Ten grape berries was homogenized and stored in $25 \mathrm{~mL}$ of physiological saline per one sample. Basic dilution $\left(10^{-1} 10^{-2} 10^{-3}\right)$ were prepared from the stock solution as follows: $0.5 \mathrm{~mL}$ of sample was added to the tube which contains $4.5 \mathrm{~mL}$ of physiological saline $(0.85 \%)$. For microorganisms' cultivation were used three types of cultivation media, to segregate individual microorganism groups. SDA was used for $\mathrm{CFU}$ segregation of yeasts (incubation 5 days at $25^{\circ} \mathrm{C}$, aerobic cultivation method), AA (incubation $48 \mathrm{~h}$ at $28^{\circ} \mathrm{C}$ ), MRS (incubation $72 \mathrm{~h}$ at $37^{\circ} \mathrm{C}$ microaerophilic cultivation method). After incubation time collect the results and starts with cleaning and identification of different microbial species. For cleaning and better identification of yeasts isolated from grapes used different media: Malt Extract agar (MEA, Biomark, India) and Glucose Yeast extract agar (GYA, Conda, Spain) with indicator bromocresol green $(0.020 \mathrm{~g} / \mathrm{L})$. The cleaned bacterial culture was further identified by Gram staining under fluorescent microscope, and with indicator bromocresol green.

\section{RESULTS AND DISCUSSION}

Grape skin was colonized by different species of bacteria and yeast. The most important microorganisms for alcoholic fermentation are yeasts. Table 1 shows the results from plate diluting method at $\log \mathrm{CFU} / \mathrm{mL}$ unit. The number of bacteria on Acetobacter agar (AA) ranged from $1.76 \log \mathrm{CFU} / \mathrm{mL}$ to $2.80 \log$ $\mathrm{CFU} / \mathrm{mL}$. The highest level of acetic acid bacteria on AA was found in grape variety Blaufränkisch $(2.80 \log \mathrm{CFU} / \mathrm{mL})$. Lactic acid bacteria were counted on MRS agar and the number of detectable colonies ranged from $0.48 \log \mathrm{CFU} / \mathrm{mL}$ to $2.06 \log \mathrm{CFU} / \mathrm{mL}$, but negative results has been obtained from white grape varieties, when lactic acid bacteria doesn't grow. The highest level of lactic acid bacteria was found in grape variety Cabernet Sauvignon $2.06 \log \mathrm{CFU} / \mathrm{mL}$, and the highest level of lactic acid bacteria was also found in Blaufränkisch grape variety at second sample. Sabouraud dextrose agar (SDA) was used for cultivation of yeast and the number of yeasts ranged from $2.47 \log \mathrm{CFU} / \mathrm{mL}$ to $2.76 \log \mathrm{CFU} / \mathrm{mL}$, and the highest level of yeasts grown up on Blaufränkisch grape variety surface.

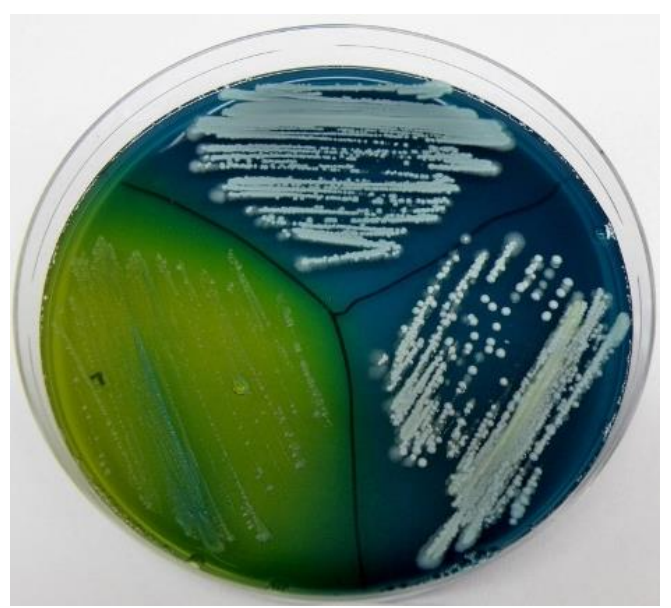

Figure 1 Acid producing yeast on MEA with Bromocresol green
Table 1 Number of microorganisms isolated from grape berries in $\log$ CFU/mL

\begin{tabular}{lcccc}
\hline Grape variety & Sample & AA & MRS & SDA \\
\hline & 1 & 2.35 & 1.20 & 2.72 \\
Blaufränkisch 2014 & 2 & 2.57 & 1.67 & 2.73 \\
& 3 & 1.94 & 1.48 & 2.72 \\
& 4 & 2.59 & 0.48 & 2.76 \\
& 5 & 2.40 & 0.48 & 2.74 \\
\cline { 2 - 5 } Cabernet Sauvignon 2014 & 1 & 1.76 & 1.70 & 2.72 \\
& 2 & 2.73 & 1.66 & 2.73 \\
& 3 & 2.29 & 1.51 & 2.73 \\
& 4 & 2.72 & 1.45 & 2.74 \\
Rhein Riesling 2014 & 5 & 2.71 & 2.06 & 2.74 \\
\cline { 2 - 5 } & 1 & 2.75 & ND & 2.72 \\
& 2 & 2.71 & ND & 2.71 \\
Welschriesling 2014 & 3 & 2.54 & ND & 2.52 \\
& 5 & 2.61 & ND & 2.55 \\
& 5 & 2.63 & ND & 2.51 \\
\hline & 1 & 2.53 & ND & 2.54 \\
& 3 & 2.67 & ND & 2.52 \\
& 4 & 2.80 & ND & 2.47 \\
& 5 & 2.49 & ND & 2.68 \\
& 2.29 & ND & 2.49 \\
\hline
\end{tabular}

AA - Acetobacter spp., MRS - Lactobacillus spp., SDA - Yeasts, ND - not detected Unit - $\log \mathrm{CFU} / \mathrm{mL}$

For identification of yeast species was used different types of agar media with acid base indicator bromocresol green. Visual interval of acid base indicator bromocresol green is varying from $\mathrm{pH} 3.8$ (yellow) to 5.4 (blue). Green color is visible at $\mathrm{pH} 4.5$ (Ibarra et al., 2004).

As seen above in table 1 the highest level of grown cultures were detected in AA and SDA agar media. AA was suitable for growing yeasts and also some yeast species grown up on MRS agar. When used the $\mathrm{pH}$ indicator bromocresol green the acid production strains were yellow or green and strains with negative or poor acid production were white, turquoise or blue. With the production of acids agar discolored to yellow under the yeasts or bacterial colonies. Table 2 shows all discovered species coloration isolated from grapes, which cultivated on different type of agar media with bromocresol green (BG) indicator.

Generally, very few yeast species $\left(10-10^{3} \mathrm{CFU} / \mathrm{mL}\right)$ are detected on immature grape berries, but they increase to populations of $10^{4}-10^{6} \mathrm{CFU} / \mathrm{mL}$ as the grapes mature to harvest. During ripening, sugars leach or diffuse from the inner tissues of the grape to the surface, thereby encouraging yeast growth. Unripe grapes harbor a predominance of Rhodotorula, Cryptococcus and Candida species. Most of these species are also isolated from mature, ripe grapes but, at this stage, species of the apiculate yeasts, Hanseniaspora (anamorph Kloeckera) and Metschnikowia, are mostly predominant. Damaged grapes have increased incidence of Hanseniaspora (Kloeckera), Candida and Metschnikowia species, as well as species of Saccharomyces and Zygosaccharomyces (Fleet, 2003).

Table 2 Positive or negative results of agar decolorization with indicator Bromocresol green

\begin{tabular}{|c|c|c|c|c|}
\hline Grape variety & $\begin{array}{l}\text { No. of } \\
\text { strain } \\
\end{array}$ & $\begin{array}{l}\text { Strain } \\
\text { Color }\end{array}$ & GYA + BG & MEA + BG \\
\hline \multirow{4}{*}{ Blaufränkisch 2014} & 1. & $\operatorname{mint}$ & \pm & - \\
\hline & 2. & blue & + & + \\
\hline & 3. & green & + & - \\
\hline & 4. & cherry & \pm & - \\
\hline \multirow{6}{*}{$\begin{array}{l}\text { Cabernet Sauvignon } \\
2014\end{array}$} & 1. & $\operatorname{mint}$ & - & - \\
\hline & 2. & white & + & - \\
\hline & 3. & transculent & + & - \\
\hline & 4. & $\begin{array}{l}\text { transculent } \\
\text { II }\end{array}$ & + & - \\
\hline & 5. & dark blue & + & - \\
\hline & 6. & purple & + & - \\
\hline \multirow{6}{*}{ Rhein Riesling 2014} & 1. & mint & + & - \\
\hline & 2. & turquoise & + & - \\
\hline & 3. & blue & + & - \\
\hline & 4. & purple & + & - \\
\hline & 5. & orange & + & - \\
\hline & 6. & transculent & + & - \\
\hline \multirow{4}{*}{ Welschriesling 2014} & 1. & cherry & \pm & - \\
\hline & 2. & purple & + & - \\
\hline & 3. & transculent & + & - \\
\hline & 4. & green & + & - \\
\hline
\end{tabular}

Although all isolated strains grown very well on MEA + BG and on GYA + BG, but the decolorization of agar media was better on GYA + BG. Isolated microorganisms from grape berries changed the GYA medium coloration after 23 days of cultivating. The bromocresol green was absorbed by microorganisms' 
strains. However next medium MEA with BG shows a negative results, but the strains were colorized by bromocresol green. In one case was the agar changes his color from deep green-blue to yellow (figure 1). This strain was produce high concentration of acids and the indicator was changed from blue to yellow. This positive result was detected at strain number two isolated from Blaufränkisch grape variety. The next table shows the differences between initially described strains on MEA + BG and strains after inoculation to new agar plates with BG Table 3 shows the colorization of mainly yeasts and bacterial strains.

\begin{tabular}{|c|c|c|c|c|}
\hline Grape variety & No. of strain & First description & GYA + BG & MEA + BG \\
\hline \multirow{4}{*}{ Blaufränkisch 2014} & 1 & $\operatorname{mint}$ & green + turquoise & mint \\
\hline & 2 & blue & green & transculent \\
\hline & 3 & green & white + dark green & mint + green \\
\hline & 4 & cherry & pinky dark green & cherry \\
\hline \multirow{6}{*}{ Cabernet Sauvignon 2014} & 1 & mint & mint + dark green & mint \\
\hline & 2 & white & white & $\operatorname{mint}$ \\
\hline & 3 & transculent & green & transculent \\
\hline & 4 & transculent II & dark green & transculent \\
\hline & 5 & dark blue & yellow green & dark blue \\
\hline & 6 & purple & yellow green & purple \\
\hline \multirow{6}{*}{ Rhein Riesling 2014} & 1 & $\operatorname{mint}$ & mint + green & mint \\
\hline & 2 & turquoise & green + turquoise & white \\
\hline & 3 & blue & green + turquoise & $\operatorname{mint}$ \\
\hline & 4 & purple & pink + dark green & purple \\
\hline & 5 & orange & dark green & cherry \\
\hline & 6 & transculent & green & transculent \\
\hline \multirow{4}{*}{ Welschriesling 2014} & 1 & cherry & pink + dark green & cherry \\
\hline & 2 & purple & pink + dark green + purple & purple \\
\hline & 3 & transculent & green & transculent \\
\hline & 4 & green & dark green + mint & dark green + mint \\
\hline
\end{tabular}

We compared the obtained descriptions by using microscope with the descriptions from other authors. Many species were isolated from grape berries. These yeast and bacteria species are includes to natural microflora of grape berries (König et al., 2009).

Numerous yeast genera and species are found during the production of wine. The low $\mathrm{pH}$ of wine, high sugar content, rapidly generated anaerobic conditions, and presence of phenolic compounds creates the ideal environment to support the growth of yeasts and to enrich these organisms over other microbes (Fleet, 2003; Romano et al., 1997).

The yeasts that impact the composition of the wine can come in with the grapes from the vineyard, can be residents of the winery flora, or can be spread by insect vectors such as fruit flies, bees, and wasps (Fleet $\boldsymbol{e t}$ al., 2002). Over twenty yeast genera have been identified from wines (Renouf et al., 2007).

There are three principal genera found on grapes: Hanseniaspora uvarum (anamorph: Kloeckera apiculata), Metschnikowia pulcherrima (anamorph: Candida pulcherrima), and Candida stellata. In some reports, Hanseniaspora is the dominant species (Beltran et al., 2002; Combina et al., 2005; Hierro et al.
2006) and in others it is Candida (Clemente-Jimenez et al., 2004; Torija et al., 2001). Candida has been shown to complete the alcoholic fermentation in some cases (Clemente-Jimenez et al., 2004). Several of the Candida stellata isolates from wine are actually Candida zemplinina (Csoma and Sipiczki, 2008).

Other yeasts can be commonly found, although they are not as universal. Saccharomyces can be detected, but is present on grape surfaces at very low levels (Prakitchaiwattana et al., 2004; Martini et al., 1996), and has been undetectable in some studies (Combina et al., 2005; Raspor et al., 2006).

We isolated and determined 10 different species of yeasts, two Lactobacillus and Acetobacter strains and one Pediococcus, Gluconobacter strain. The most dominant species in this study were Hanseniaspora uvarum, Metschnikowia pulcherima, Hansenula anomala, Kluyveromyces marxianus and Candida stellata. We also isolated Pichia, Debaryomyces, Dekkera and Saccharomyces yeasts from grape surfaces. Table 4 shows the results from determined and detected species on grape berries.

Table 4 Isolated microorganisms from grape berries

\begin{tabular}{|c|c|c|c|c|}
\hline Grape variety & No. of strain & Yeast & Bacteria & Reference \\
\hline \multirow{2}{*}{ Blaufränkisch 2014} & 1 & Candida sp. & ND & Konig et al., 2009 \\
\hline & 3 & Hansenula anomala, Debaryomyces hansenii & Lactobacillus sp. & Fleet, 2003, Andriy et al., 2009 \\
\hline \multirow{4}{*}{ Cabernet Sauvignon 2014} & 1 & Pichia anomala & ND & Fleet, 2003 \\
\hline & 2 & Hansenula anomala & ND & Fleet, 2003 \\
\hline & 3 & Dekkera bruxellensis & Gluconobacter sp. & Konig et al., 2009 \\
\hline & 6 & Kluyveromyces marxianus & ND & Kourkoutas et al., 2002 \\
\hline \multirow{5}{*}{ Rhein Riesling 2014} & 1 & Pichia anomala & ND & Fleet, 2003 \\
\hline & 2 & Hansenula anomala & ND & Fleet, 2003 \\
\hline & 3 & Candida sp. & ND & Konig et al., 2009 \\
\hline & 4 & Kluyveromyces marxianus & ND & Kourkoutas et al., 2002 \\
\hline & 5 & Rhodotorula mucilaginosa & Acetobacter sp. & Quesada et al., 1995 \\
\hline \multirow{2}{*}{ Welschriesling 2014} & 3 & Hanseniaspora uvarum & ND & Delfini et al., 2002 \\
\hline & 4 & Metschnikowia pulcherrima & $\mathrm{ND}$ & Fernández et al., 2000 \\
\hline
\end{tabular}




\section{CONCLUSION}

Natural microflora of grape berries is very diverse. After plate diluting method shows us that the most various microorganisms on grape berry surface are yeasts More lactic acid bacteria colonies grow up from blue grape varieties Blaufränkisch 2014 and Cabernet Sauvignon 2014 cultivated on MRS, but on white varieties Rhein Riesling 2014 and Welschriesling 2014 doesn't grow up The detection level of yeast was very similar on all tested samples of grape berries. By microscopic determination identified different yeast species includes to 10 genera. We tried to cultivate acetic acid bacteria on Acetobacter agar, but as shows the results sooner, yeast grow very well on this agar, and after gram staining and microscopic determination we isolated only 2 Acetobacter and one Gluconobacter strain. We detected on grape berries only three strains of lactic acid bacteria.

Acknowledgements: The Paper was supported by the project: The research leading to these results has received funding from the European Community under project no 26220220180: Building Research Centre „AgroBioTech“, by grant of VEGA 1/0611/14.

\section{REFERENCES}

ANDRIY, A.S., ANDRIY Y.V. 2009. Candida famata (Debaryomyces hansenii). In: Yeast Biotechnology: Diversity and Applications. ISBN 978-1-4020-8292-4 85-111. http://dx.doi.org/10.1007/978-1-4020-8292-4_5

ARENA, M.P., ROMANO, A., CAPOZZI, V., BENEDUCE, L., GHARIANI, M., GRIECO, F., LUCAS, P., SPANO, G. 2011. Expression of Lactobacillus brevis IOEB 9809 tyrosine decarboxylase and agmatine deaminase genes in wine correlates with substrate availability. Letters in Applied Microbiology, 53, 395402. http://dx.doi.org/10.1111/j.1472-765x.2011.03120.x

ARROYO-LÓPEZ, F.N., SALVADÓ, Z., TRONCHONI, J., GUILLAMÓN, J.M., BARRIO, E., QUEROL, A. 2010. Susceptibility and resistance to ethanol in Saccharomyces strains isolated from wild and fermentative environments. Yeast, 27, 1005-1015. http://dx.doi.org/10.1002/yea.1809

BARTOWSKY, E.J. 2009. Bacterial spoilage of wine and approaches to minimize it. Letters in Applied Microbiology, 48, 149-156. http://dx.doi.org/10.1111/j.1472-765x.2008.02505.x

BELTRAN, G., TORIJA, M.J., NOVO, M., FERRER, N., POBLET, M., GUILLAMON, J.M., ROZES, N., MAS, A. 2002 Analysis of yeast populations during alcoholic fermentation: A six year follow-up study. Systematic and Applied Microbiology, 25, 287-293. http://dx.doi.org/10.1078/0723-2020-00097 CAPOZZI, V., LADERO, V., BENEDUCE, L., FERNANDEZ, M., ALVAREZ, M.A., BENOIT, B., LAURENT, B., GRIECO, F., SPANO, G. 2011. Isolation and characterization of tyramine-producing Enterococcus faecium strains from red wine. Food Microbiology, 28, 434-439. http://dx.doi.org/10.1016/j.fm.2010.10.005

CLEMENTE-JIMENEZ, J.M., MINGORANCE-CARZOLA, L., MARTINEZRODRIGUEZ, S., LAS HERAS-VAZQUEZ, F.J., RODRIGUEZ-VICO, F. 2004. Molecular characterization and oenological properties of wine yeasts isolated during spontaneous fermentation of six varieties of grape must. Food Microbiology, 21, 149-155. http://dx.doi.org/10.1016/s0740-0020(03)00063-7 COMBINA, M., MERCADO, L., BORGO, P., ELIA, A., JOOFRE, V., GANGA, A., MARTINEZ, C., CATANIA, C. 2005. Yeasts associated to Malbec grape berries from Mendoza, Argentina. Journal of Applied Microbiology, 98, 10551061. http://dx.doi.org/10.1111/j.1365-2672.2005.02540.x

CSOMA, H., SIPICZKI, M. 2008. Taxonomic reclassification of Candida stellata strains reveals frequent occurrence of Candida zemplinina in wine fermentation. FEMS Yeast Research, 8, 328-336. http://dx.doi.org/10.1111/j.1567-1364.2007.00339.x

DAVENPORT, R.R. 1974. Micro-ecology of yeasts and yeast like organisms associated with an English vineyard. Vitis, 13, 123-130.

DE ANDRÉS-DE PRADO, R., YUSTE-ROJAS, M., SORT, X., ANDRÉS LACUEVA, C., TORRES, M., LAMUELA-RAVENTÓS, R.M. 2007. Effect of soil type on wines produced from Vitis vinifera $L$. C v. Grenache in commercial vineyards. Journal of Agricultural and Food Chemistry, 55 (3), 779-786. http://dx.doi.org/10.1021/jf062446q

DELFINI, C., GAIA, P., SCHELLINO, R., STRANO, M., PAGLIARA, A. AMBRÓ, S. 2002. Fermentability of grape must after inhibition with dimethyl dicarbonate (DMDC). Journal of Agricultural and Food Chemistry, 50, 56055611. http://dx.doi.org/10.1021/jf0256337

DIVOL, B., LONVAUD-FUNEL, A. 2005. Evidence for viable but nonculturable yeasts in botrytis-affected wine. Journal of Applied Microbiology, 99, 85-93. http://dx.doi.org/10.1111/j.1365-2672.2005.02578.x

DU TOIT, W.J., PRETORIUS, I.S., LONVAUD-FUNEL, A. 2005. The effect of suphur dioxide and oxygen on the viability and culturability of a strain of Acetobacter pasteurianus and a strain of Brettanomyces bruxellensis isolated from wine. Journal of Applied Microbiology, 98, 862-871. http://dx.doi.org/10.1111/j.1365-2672.2004.02549.x

FERNÁNDEZ, M., ÚBEDA, J.F., BRIONES, A.I. 2000. Typing of nonSaccharomyces yeasts with enzymatic activities of interest in wine-making.
International Journal of Food Microbiology, 59, 29-36. http://dx.doi.org/10.1016/s0168-1605(00)00283-x

FLEET, G.H. 1990. Growth of yeasts during wine fermentations. Journal of Wine Research, 1, 211-223. http://dx.doi.org/10.1080/09571269008717877

FLEET, G.H. 2003. Yeast interactions and wine flavour. International Journal of Food Microbiology, 86, 11-22. http://dx.doi.org/10.1016/s0168-1605(03)00245-9 GONZÁlES, Á., GUILLAMÓN, J.M., MAS, A., POBLET, M. 2006. Application of molecular methods for routine identification of acetic acid bacteria. International Journal of Food Microbiology, 108, 141-146. http://dx.doi.org/10.1016/j.ijfoodmicro.2005.10.025

HIERRO N, GONZALES, A., MAS, A., GUILLAMON, J.M. 2006. Diversity and evolution of non-Saccharomyces yeast populations during wine fermentation: effect of grape ripeness and cold maceration. FEMS Yeast Research, 6, 102-111. http://dx.doi.org/10.1111/j.1567-1364.2005.00014.x

IBARRA, J.C., ORTIZ-GUTIÉRREZ, M., ALONSO-MAGANA， P. 2004. Characterization of bromocresol green and resin as holographic film. Optical Materials, 27, 567-572. http://dx.doi.org/10.1016/j.optmat.2004.06.003

JOSEPA, S. 2000. PCR differentiation of Saccharomyces cerevisiae from Saccharomyces bayanus/Saccharomyces pastorianus using specific primers. FEMS Microbiology Letters, 193，255-259. http://dx.doi.org/10.1016/s03781097(00)00458-4

KÖNIG, H., FRÖHLICH, J., UNDEN, G. 2009. Biology of Microorganisms on Grapes, in Must and in Wine, Springer-Verlag, Berlin Heidelberg, ISBN 978-3540-85462-3. http://dx.doi.org/10.1007/978-3-540-85463-0

KOURKOUTAS, Y., DIMITROPOULOU, S., KANELLAKI, M., MARCHANT, R., NIGAM, P., BANAT, I.M., KOUTINAS, A. 2002. Hightemperature alcoholic fermentation of whey using Kluyveromyces marxianus IMB3 yeast immobilized on delignified cellulosic material. Bioresource Technology, 82, 177-181. http://dx.doi.org/10.1016/s0960-8524(01)00159-6

LERM, E., ENGELBRECHT, L., DU TOIT, M., 2010. Lactobacillus: the Next Generation of Malolactic Fermentation Starter Cultures - an Overview. Food and Bioprocess Technology, 4, 876-906. http://dx.doi.org/10.1007/s11947-010-0448-

LONVAUD-FUNEL, A. 1999. Lactic acid bacteria in the quality improvement and depreciation of wine. Antonie Van Leeuwenhoek, 76, 317-331. http://dx.doi.org/10.1007/978-94-017-2027-4_16

MARTINI, A. 1993. Origin and domestication of the wine yeast Saccharomyces cerevisiae. Journal of Wine Research, 4, 165-176. http://dx.doi.org/10.1080/09571269308717966

MARTINI, A., CIANI, M., SCORZETTI, G. 1996. Direct enumeration and isolation of wine yeasts from grape surfaces. American Journal of Enology and Viticulture, 47, 435-440.

MILLET, V., LONVAUD-FUNEL., A. 2000. The viable but non-culturable state of wine microorganisms during storage. Letters of Applied Microbiology, 30 136-141. http://dx.doi.org/10.1046/j.1472-765x.2000.00684.x

OLIVER, J.D. 2005. The viable but non-culturable state in bacteria. Journal of Microbiology, 43, 93-100.

PAN, W., JUSSIER, D., TERRADE, N., YADA, R.Y., MIRADE-ORDUNA, R., 2011. Kinetics of sugars, organic acids and acetaldehyde during simultaneous yeast-bacterial fermentations of white wine at different $\mathrm{pH}$ values. Food $\begin{array}{llll}\text { Research International, 660-666. } & \text { 44, }\end{array}$ http://dx.doi.org/10.1016/j.foodres.2010.09.041

PARRISH, M.E., CARROL, D.E. 1985. Indigenous yeast associated with muscadine (Vitis rotundifolia) grapes and musts. American Journal of Enology and Viticulture, 36, 165-169.

PRAKITCHAIWATTANA, C.J., FLEET, G.H., HEARD, G.M. 2004 Application and evaluation of denaturing gradient gel electrophoresis to analyse the yeast ecology of wine grapes. FEMS Yeast Research, 4, 865-877. http://dx.doi.org/10.1016/j.femsyr.2004.05.004

PRETORIUS, I.S. 2000. Tailoring wine yeast for the new millennium: Novel aproaches to the ancient art of winemaking. Yeast, 16, 675-729. http://dx.doi.org/10.1002/1097-0061(20000615)16:8<675::aid-yea585>3.3.co;2-2 PRETORIUS, I.S., VAN DER WESTHUIZEN, T.J., AUGUSTYN, O.P.H. 1999. Yeast diversity in vineyards and wineries and its importance to the South African wine industry. South African Journal of Enology and Viticulture, 20, 61-74.

QUESADA, M., CENIS, J. 1995. Use of Random Amplified Polymorphic DNA in the characterization of wine yeasts. American Journal of Enology and Viticulture, 46 (2), 204-208.

RASPOR, P., MILEK, D.M., POLANC, J., SMOLE MOZINA, S., CADEZ, N. 2006. Yeasts isolated from three varieties of grapes cultivated in different locations of the Dolenjska vine-growing region, Slovenia. International Journal of Food Microbiology, $109, \quad 97-102$ http://dx.doi.org/10.1016/j.ijfoodmicro.2006.01.017

RENOUF, V., CLAISSE, O., LONVAUD-FUNEL, A. 2007. Inventory and monitoring of wine microbial consortia. Applied Microbiology and Biotechnology, 75, 149-164. http://dx.doi.org/10.1007/s00253-006-0798-3

ROMANO, P., SUZZI, G., COMI, G., ZIRONI, R., MAIFRENI, M. 1997. Glycerol and other fermentation products of apiculate wine yeasts. Journal of Applied Microbiology, 82, 615-618. http://dx.doi.org/10.1111/j.13652672.1997.tb02870.x 
ROSINI, G., FEDERICI, F., MARTINI, A. 1982. Yeast flora of grape berries

during ripening. Microbial Ecology, 8, 83-89.

http://dx.doi.org/10.1007/bf02011464

TORIJA, M.J., ROZES, N., POBLET, M., GUILLAMON, J.M., MAS, A. 2001.

Yeast population dynamics in spontaneous fermentations: comparison between two different wine-producing areas over a period of three years. Antonie van Leeuwenhoek, 79, 345-352. http://dx.doi.org/10.1023/a:1012027718701

VELÁZQUEZ, J.B., LONGO, E., CANSADO, J., VILLA, T.G., SIEIRO, C., CALO, P. 1991. Improvement of the alcoholic fermentation of grape juice with mixed cultures of Saccharomyces cerevisiae wild strains. Negative effect of Kloeckera apiculata. World Journal of Microbiology \& Biotechnology, 7, 485489. http://dx.doi.org/10.1007/bf00303374 